Article

\title{
Exploring the Introduction of Plug-In Hybrid Flex-Fuel Vehicles in Ecuador
}

\author{
Danilo Arcentales 1,2 (iD) and Carla Silva ${ }^{2, *(D)}$ \\ 1 Escuela Superior Politécnica del Litoral, ESPOL, Facultad de Ingeniería en Ciencias de la Tierra, Campus \\ Gustavo Galindo Km. 30.5 Vía Perimetral, P.O. Box 09-01-5863, Guayaquil, Ecuador; daanarce@espol.edu.ec \\ 2 Instituto Dom Luiz, Faculdade de Ciências, Universidade de Lisboa, 1749-016 Lisbon, Portugal \\ * Correspondence: camsilva@fc.ul.pt
}

Received: 21 March 2019; Accepted: 8 June 2019; Published: 13 June 2019

check for updates

\begin{abstract}
In Europe, diesel combustion is being banned due to the $\mathrm{NO}_{\mathrm{x}}$ and $\mathrm{PM}_{2.5}$ emissions impact on air quality. The bus sector is being electrified and is increasing its use of alternative fuels, such as natural gas (in spark ignition engines) and bioethanol (in compression ignition engines), to reduce such harmful emissions. Even if a diesel bus is equipped with selective catalytic reduction (SCR), its $\mathrm{NO}_{x}$ emissions are reduced its but produces more $\mathrm{NH}_{3}$ emissions that are $\mathrm{PM}_{2.5}$ precursors. In developing countries, the air quality is still barely monitored, however, the air quality issue is well known and is being addressed. Moreover, the Ecuadorian sugar cane industry is seeking ways to increase its ethanol production. This is the ideal framework to explore a new technology and energy source in developing economies such as Ecuador. This paper explores the impact of the Ecuadorian diesel bus fleet conversion to hybrid compression ignition ethanol (HEV-ED95), hybrid diesel and plug-in hybrid flex-fuel using electricity and internal combustion engine ICE-E20 and ICE-E100. The impacts are measured in terms of final energy consumption, criteria pollutant emissions $\left(\mathrm{NH}_{3}, \mathrm{NO}_{\mathrm{x}}, \mathrm{PM}_{2.5}\right)$ and 100 years global warming potential in a well-to-wheels framework. For the tank-to-wheels data the method follows the typical values of conversion efficiency from final to useful energy (cross checked with a microsimulation model), the Tier 2 European Environmental Agency approach combined with ethanol influence on compression ratio, lower heating value, criteria emissions taken from a literature review, and well-to-tank emission factors for electricity (10-58\% thermal natural gas or coal powerplant contribution), for ethanol from banana industry wastes (ED95, E20 and E100), gasoline and diesel from US databases. A discussion on whether sugarcane biorefineries are necessary is highlighted in the results. All input parameters have an uncertainty range between a minimum and a maximum and the probability for each is giving by a uniform distribution.
\end{abstract}

Keywords: final energy; new bus technology; $\mathrm{NO}_{x} ; \mathrm{PM}_{2.5} ; \mathrm{NH}_{3}$; ethanol

\section{Introduction}

The transport sector contribution to crude oil depletion, climate change, and air quality degradation is worrisome. For example, according to the International Energy Agency (IEA) in 2016 the transport sector was accountable for $25 \%$ of greenhouse gas (GHG) emissions. According to the same source, it also consumes $98 \%$ of crude oil-based fuels. Additionally, road transport represents $40 \%$ of $\mathrm{NO}_{\mathrm{x}}$ emissions, and is the main source of $\mathrm{PM}_{2.5}$ in cities.

It is very likely that the focus on reducing $\mathrm{NO}_{x}$ emissions cause an increase in $\mathrm{NH}_{3}$ slip aggravated by catalyst ageing [1,2]. Ammonia is an inorganic compound that, in presence of acid gases, can generate atmospheric ammonium aerosol salts [3]. Knowledge of $\mathrm{NH}_{3}$ tailpipe emissions is therefore important.

The road transportation sector in Ecuador is characterized by its use of fossil fuels as the main source of energy. According to INEC (the Spanish acronym for Instituto Nacional de Estadísticas 
y Censos-National Institute of Statistics and Census in English), the transportation sector emitted 18.5 million tons of GHG, which correspond to $42 \%$ of the emissions from all sectors [4]. Due to the accelerated urbanization in the main Ecuadorian cities, local governments have been forced to implement new transport systems such as bus rapid transit (BRT). The most economical way to commute in Ecuador is by bus, which is also the most used means of transport. Counting regional, urban, public and international buses, there are approximately 23,400 buses where $98 \%(23,056)$ correspond to diesel-based buses and the other 2\% (380) are gasoline-based buses, mainly used by schools. Recently, a bus line in Guayaquil purchased 20 electric buses for its daily operations, becoming the second South American city to have an electric bus fleet.

In 2010, the Eco País E5 Pilot Program (E5 = 5\% ethanol content in gasoline type rated above 85 octanes) started in the cities of Guayaquil and Durán. Initially, the government aimed to increase the ethanol blend with gasoline from 5 to $15 \%$ by 2016 . However, in order to reach this target, 400 million litres (L) of ethanol are needed per year. The sugarcane cultivated area must add 66 thousand hectares to the existing 79 thousand hectares. By 2015, this program covered 86 percent of demand for extra fuel in the Guayas Province. Ecuadorian sugarcane and alcohol producers were able to produce 80 million L of ethanol. Ecuador's three major sugarcane companies produce most of this ethanol: Valdez with Codana, San Carlos with Soderal and Coazucar with Producargo.

Banana industry wastes were explored as another potential source of ethanol $[5,6]$. These studies claim that Ecuador has the potential to produce an additional 118-266 L ethanol/ha on a yearly basis from this feedstock. Considering the roughly 150,000 ha in banana production, this would mean an extra 40 million $\mathrm{L}$ of ethanol a year.

Ecuador is also experiencing a change in electric power generation, moving heavily to renewables [7]. By 2014, Ecuador had an installed capacity of $5299 \mathrm{MW}$, with a thermal-based capacity share of $21 \%$, an internal combustion engine share of $25 \%$, a hydro-based capacity of $42 \%$, and the remainder from biomass, solar and wind-based capacity. The government forecasted that this capacity would be approximately $7800 \mathrm{MW}$ by 2018, with the main contribution coming from large-scale hydro. In 2017 the mix was $56.1 \%$ renewables and $43.9 \%$ non-renewables with distribution losses of $12.1 \%$.

By May 2017, Ecuador presented its National Plan of Energy Efficiency (PLANEE, for its acronym in Spanish) whose objective was to use electricity in an efficient way and to include the promotion of new technologies in the transportation sector [8,9]. To the best of our knowledge, there is no information regarding possible pollutants mitigation achievements in the mass transportation sector in Ecuador.

This paper aims at exploring different bus concept options and their impacts on final energy consumption, air quality and 100 years global warming impact. The bus concepts are: compression ignition running on diesel $\left(\mathrm{ICEV}_{\mathrm{CI}}\right)$, hybrid with compression ignition engine running on diesel $\mathrm{HEV}_{\text {diesel }}$, hybrid with compression ignition engine running on ethanol-based fuel for diesel engines (ED95) $\mathrm{HEV}_{\mathrm{ED} 95}$, and plug-in hybrid with flex-fuel spark ignition engine, running on ethanol E20 and E100 PHEV flex.

The impacts are measured in terms of final energy consumption, $\mathrm{NO}_{x}, \mathrm{PM}_{2.5}$ and $\mathrm{NH}_{3}$ (converted to PM2.5 equivalent), and $\mathrm{CO}_{2}$ eq through different replacement scenarios. $\mathrm{NH}_{3}$ is already included in standards by imposing a limit of 10 ppm, for SCR equipped buses and based on Equation (3) from Stelwagen and Ligterink [2], this would probably mean $46 \mathrm{mg} / \mathrm{km} \mathrm{NH}_{3}$ slip. Ecuador follows European emission standards so we are going to stick with European emission models for the tank-to wheels (TTW) data.

\section{Materials and Methods}

The aim of this study is to compare the final energy consumption and local environmental impacts of six scenarios considering different fuels (diesel, ethanol blend and electricity) and bus technologies (compression ignition, spark ignition and plug-in hybrid flex-fuel) (Table 1). The scope of the study is 
the so called well-to-wheels (WTW) analysis. It is divided into tank-to-wheels (TTW) according to the matrix of powertrains/fuels in Table 1 and well-to-tank (WTT) according to Table 2.

Table 1. Matrix for TTW energy consumption and emissions calculations.

\begin{tabular}{ccccc}
\hline Technology/Fuel & Diesel & E20 & E100 & Electricity \\
\hline ICEV compression ignition $(\mathrm{CI})$ & $\mathrm{x}$ & & & \\
HEV (CI) & $\mathrm{x}$ & & $\mathrm{x}$ & \\
PHEV spark ignition (SI) & & $\mathrm{x}$ & $\mathrm{x}$ & $\mathrm{x}$ \\
\hline
\end{tabular}

The general formulation for final energy consumption (TTW) of a fleet with several powertrain technologies and vehicle ages (equivalent to standard) is:

$$
\begin{aligned}
E C= & \sum_{y} \sum_{m(\text { liquid/gas fuel })}\left(N V_{m, y, z} \times M_{m, y, z} \times F I_{y, z, m} L H V_{m} \rho_{m}\right) \\
& +\sum_{y}\left(N V_{\text {electric } y, z} \times M_{y, \text { electric }} \times F I_{y, z, \text { electric }} * 3.6\right)
\end{aligned}
$$

where $E C$ stands for the final energy consumption of the fleet (MJ/year); $M_{m, y, z}(\mathrm{~km} /$ year), is the average annual distance driven per vehicle of category $y$, standard $z$, and fuel $\mathrm{m}$, excluding electric miles; $N_{m, y, z}$ is the number of vehicles of category $y$, standard $z$, and fuel $m ; F I_{y, z, m}$ is the average fuel intensity of the vehicle $(\mathrm{L} / \mathrm{km}$ or $\mathrm{kWh} / \mathrm{km})$; and $L H V_{m}$ is the lower heating value of the liquid/gas fuel $m$.

The general model for emission, $E_{x}$, where $x$ stands for each pollutant, $\mathrm{NO}_{\mathrm{x}}, \mathrm{PM}_{2.5} \mathrm{or} \mathrm{NH}_{3}$ is:

$$
E_{x}=\sum_{m(\text { liquid } / \text { gas }} \sum_{\text {fuels })} \sum_{y}\left(N V_{m, y, z} \times M_{m, y, z} \times E F_{x, m, y, z}\right)
$$

where, $E F_{x, y, z}(\mathrm{~g} / \mathrm{km})$, is the specific emission factor of pollutant $x$, for vehicle category $y$, emission standard $z$ and liquid fuel $m ; E_{x}$ is the emissions of pollutant $x$.

Ammonia is a colourless gas present in the atmosphere, which reacts with acid gases $\left(\mathrm{H}_{2} \mathrm{SO}_{4}\right.$, $\mathrm{HNO}_{3}$, etc.) to produce atmospheric ammonium aerosol salts and particles such as ammonium sulfate ([NH4] $\left.]_{2} \mathrm{SO}_{4}\right)$, ammonium bisulphate $\left(\mathrm{NH}_{4} \mathrm{HSO}_{4}\right)$, ammonium nitrate $\left(\mathrm{NH}_{4} \mathrm{NO}_{3}\right)$, and ammonium chloride $\left(\mathrm{NH}_{4} \mathrm{Cl}\right)$. Knowledge of $\mathrm{NH}_{3}$ tailpipe emissions is therefore important. To convert $\mathrm{NH}_{3}$ tailpipe emissions into PM2.5 equivalent the following chemical reactions will be considered:

$$
\begin{gathered}
2 \mathrm{NH}_{3} \text { (gas) }+\mathrm{H}_{2} \mathrm{SO}_{4} \Leftrightarrow\left(\mathrm{NH}_{4}\right)_{2} \mathrm{SO}_{4} \text { (particle) } \\
\mathrm{NH}_{3} \text { (gas) }+\mathrm{HNO}_{3} \text { (gas) } \Leftrightarrow \mathrm{NH}_{4} \mathrm{NO}_{3} \text { (particle) } \\
\mathrm{NH}_{3} \text { (gas) }+\mathrm{HCl} \text { (gas) } \Leftrightarrow \mathrm{NH}_{4} \mathrm{Cl} \text { (particle) }
\end{gathered}
$$

The mass to mass ratio of particle to $\mathrm{NH}_{3}$ for these equations is, respectively, 132.14/34.062, 80.043/17.031 and 53.491/17.031. An average factor of 3.91 is assumed for the $\mathrm{PM}_{2.5}$ equivalent. Fuel consumption and emissions for new technologies will be compared with the baseline scenario to analyse their future insertion.

Our approach is based on real data from conventional bus fuel intensity to which we then applied final to useful energy efficiencies to get our exploratory flex-fuel engine PHEV final ethanol and electricity consumption. This is a simplified approach and was "cross checked" against the ADVISOR microsimulation model [10-12] for ICEV, HEV and PHEV over a specific driving cycle (driving schedule). Figure 1 presents the procedure schematic. 
Table 2. Matrix for WTT CO2eq emission factors.

\begin{tabular}{ccc}
\hline Energy Source & Min & Max \\
\hline Diesel [13] $\left(\mathrm{gCO}_{2} \mathrm{eq} / \mathrm{MJ}\right)$ & $17.5\left(621.1^{*}\right)$ & $23.5(834.0 *)$ \\
Gasoline [13] $\left(\mathrm{gCO}_{2} \mathrm{eq} / \mathrm{MJ}\right)$ & $19.7(654.4 *)$ & $26.3\left(873.4^{*}\right)$ \\
electricity $(10 \%$ thermal based) $\mathrm{g} / \mathrm{kWh}$ & 34.1 (natural gas) & $102.4($ coal) \\
electricity $(58 \%$ thermal based) $\mathrm{g} / \mathrm{kWh}$ & 198.0 (natural gas) & $593.9(\mathrm{coal})$ \\
ethanol from banana waste $[6](\mathrm{g} / \mathrm{MJ})$ & $23.6\left(540.2^{*}\right)$ & $23.6(540.2 *)$ \\
\hline
\end{tabular}

* $\mathrm{g} / \mathrm{L}$; using $794 \mathrm{~kg} / \mathrm{m}^{3}$ and LHV $28.8 \mathrm{MJ} / \mathrm{kg}$ for ethanol; $0.845 \mathrm{~kg} / \mathrm{L}$, with LHV of $42 \mathrm{MJ} / \mathrm{kg}$ for diesel; $0.755 \mathrm{~kg} / \mathrm{L}$ and $\mathrm{LHV}$ of $44 \mathrm{MJ} / \mathrm{kg}$ for gasoline.

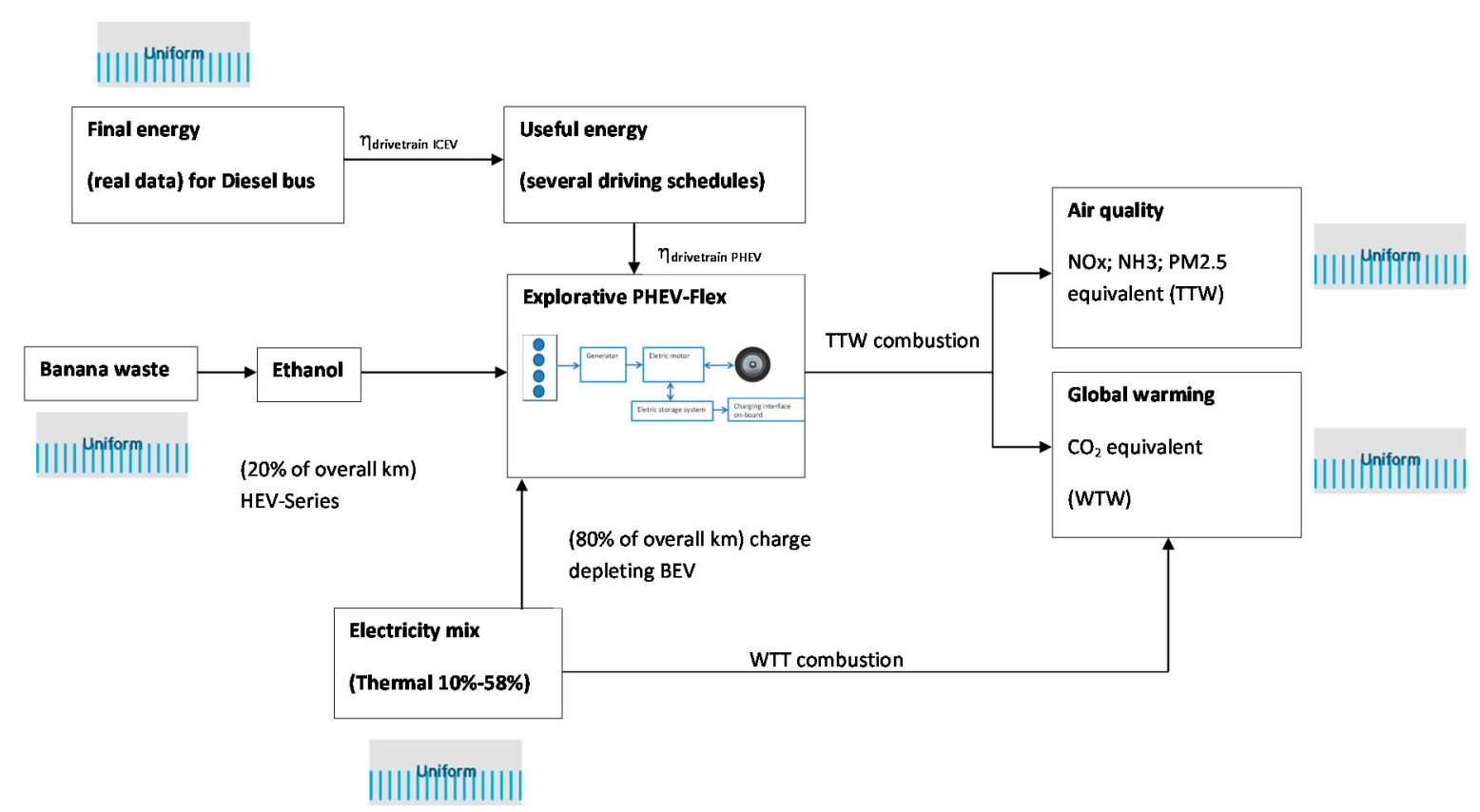

Figure 1. Simplified model scheme for air quality indicators tank-to-wheels (TTW) and global warming impact well-to-wheels (WTW) evaluation/graphical abstract.

As a "cross check" of the final to useful energy conversion efficiencies, the driving cycle was the World Harmonized Heavy Duty cycle [14], with $40 \mathrm{~km} / \mathrm{h}$ average speed, $20 \mathrm{~km}$ distance and 12 stop-\&-go situations.

\subsection{Reference Scenario-100\% ICEV Diesel Fleet}

The inventory of the number of bus vehicles in Ecuador and the fuel used was obtained from the Transport Statistics Yearbook published by the Instituto Nacional de Estadísticas y Censos (INEC) [4]. The fuel consumption, Equation (1) and emissions, Equation (2), were estimated using a bottom-up approach and following the guidelines of the Tier 2 methodology of the European Environmental Agency (EEA) (previous CORINAIR) [15].

The average annual distance was calculated using a 2016 database provided by the Ecuador Municipal Transit Authority of Guayaquil. The database presents odometer readings from several buses during inspection. Most of the buses have more than one inspection during the year, thus, two mileage records. Hence, the subtraction of two mileages recorded at different times divided by the time between both records gives us the average daily distance travelled. The other inputs needed for fuel consumption and emission calculations such as fuel intensity and emissions factors are shown in Table 7. The overall efficiency is a product of the powertrain components efficiency.

The efficiency of the diesel bus engine (ICEV buses, Figure 2) was assumed to be $38-47 \%[16,17]$, including heat losses, friction, pumping work and auxiliaries like lights, power steering, brake booster and a sound system, etc. The transmission efficiency is typically $70-80 \%$ [18]. Therefore, we assume 
$26.6-37.6 \%$ for the diesel driveline (TTW efficiency) diesel density is $0.845 \mathrm{~kg} / \mathrm{L}$, with an LHV of 42 $\mathrm{MJ} / \mathrm{kg}$ [19]. These values are to be "cross checked" using microsimulation software. Diesel engine technology will be referred to as compression ignition (CI) and spark ignition (SI) engine technology.

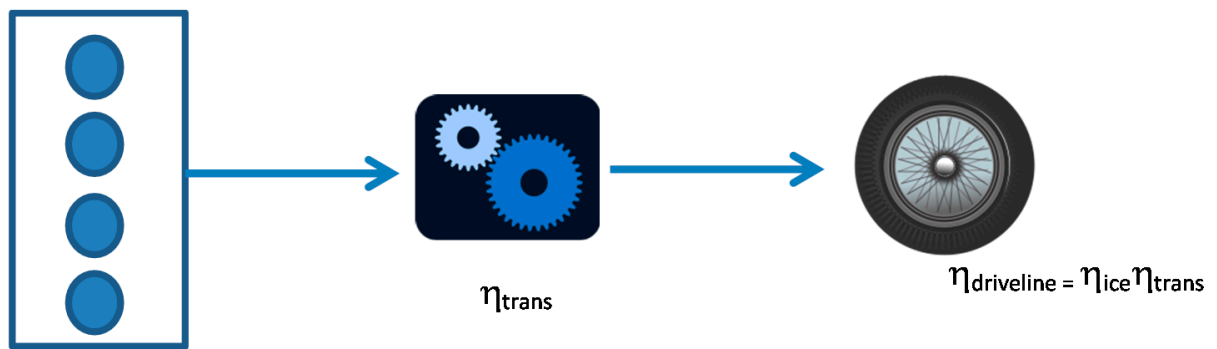

$\eta_{\text {ice }}=\eta_{\text {pumping }} \eta_{\text {heat }} \eta_{\text {friction }} \eta_{\text {auxiliaries }}$

Figure 2. Conventional compression ignition/spark ignition powertrain.

\subsection{Hypothetical Scenarios HEV with ED95}

It is already possible to run a $\mathrm{CI}$ engine with ethanol by using a higher compression ratio and additives. This HEV-ED95 runs on $95 \%$ ethanol and $5 \%$ additives to help self-ignition. A bus with this technology is commercialized by Scania. The OmniLink ethanol hybrid bus is based on series hybrid technology (S-HEV) (Figure 3 and Table 3).

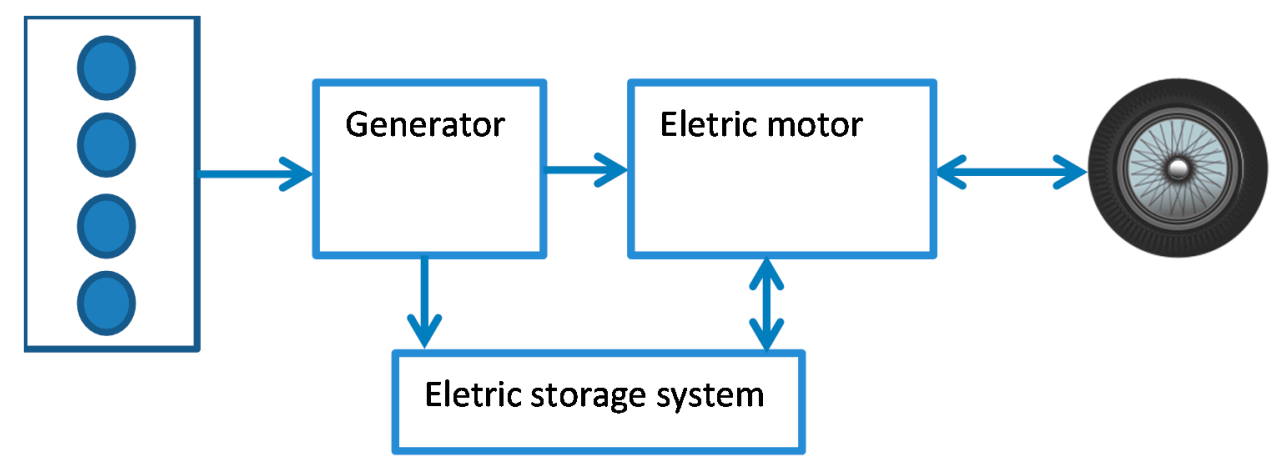

Figure 3. HEV-ED95 hybrid powertrain.

Table 3. Technical specifications of Scania Omnilink HEV-ED95 bus.

\begin{tabular}{ll}
\hline Electric Motor & Voith TFM Max 150 kW/Max 2750 Nm \\
\hline Energy Storage System & Maxwell supercapacitor 0.4 kWh \\
\hline Passenger Capacity & 114 \\
\hline Curb weight & 16 ton \\
\hline & Max. output $270 \mathrm{hp}(198 \mathrm{~kW})$ \\
Engine & Max. torque between $1250 \mathrm{Nm}$ \\
& No. of cylinders 6 \\
& Displacement $9 \mathrm{dm}^{3}$ \\
& Compression ratio of $28: 1$ \\
\hline
\end{tabular}

For real measurements, we only found a VTT Technical Research Centre of Finland Ltd. study where an HEV-ED95 bus was measured using a chassis dynamometer roller bench., recording 16.5 MJ/km for empty bus fuel consumption, $5.58 \mathrm{~g} / \mathrm{km}$ for $\mathrm{NO}_{\mathrm{x}}$, and $0.037 \mathrm{~g} / \mathrm{km}$ for PM [20]. This data is available through the LIPASTO traffic emissions database. In terms of TTW efficiency, and according to this report, the real measured fuel consumption was $0.73 \mathrm{~L} / \mathrm{km}$. 


\subsection{Hypothetical Scenarios PHEV with E20 and E100}

The flex-fuel SI engine in a hybrid powertrain is already being addressed by passenger car manufacturers, e.g., Toyota presented an initial design of the first hybrid flexible-fuel vehicle (Hybrid FFV), in Sao Paulo, Brazil. The efficiency gains could be up to $6 \%$ with ethanol blends [21]. However, this technology is not yet available on buses. This is the reason our study is exploratory and we do not have experimental data on this new hypothetical bus type. Additionally, since there are several energy management strategies for the PHEV powertrain, the flex emission data must be estimated based on emission factors. Our reasoning is therefore supported by efficiency logic and available literature data.

Usually, the efficiency of a diesel engine is $30 \%$ higher than $\eta_{\text {ice }}$ of SI engines [22]. Hence the TTW efficiency for the hypothetical flex-fuel driveline is $\left(26.6 / 1.3 * 1.06 \_37.6 / 1.3 * 1.06\right.$; or 21.7_30.7\%). The driveline efficiency ratio between SI and CI is near the $85 \%$ found in literature [23].

The lower heating value of the blend is calculated by Equation (4), where "blend" stands for ethanol \%, e.g., E20 would be $20 \%$ :

$$
\operatorname{LHV}_{\text {blend }}=(1-\text { blend } / 100) * \operatorname{LHV}_{\text {gasoline }}+\text { blend } / 100 * \operatorname{LHV}_{\text {ethanol }}
$$

The density follows the same procedure. Ethanol density is $794 \mathrm{~kg} / \mathrm{m}^{3}$ and LHV $28.8 \mathrm{MJ} / \mathrm{kg}$ [19]. Gasoline $755 \mathrm{~kg} / \mathrm{m}^{3}$ and $44 \mathrm{MJ} / \mathrm{kg}$ [19]. The effect ethanol blends have on $\mathrm{CO}_{2}$ emissions is direct from combustion mass balance (assuming $\mathrm{C}_{8} \mathrm{H}_{18}$ for gasoline), the equation is:

$$
\mathrm{ECO}_{2}\left[\mathrm{~kg} / \mathrm{kg}_{\text {fuel }}\right]=(1-\text { blend } / 100) \times 3.0877+\text { blend } / 100 \times 1.9130=0.0117 * \text { blend }+3.0877
$$

For the effect of ethanol blend on $\mathrm{NO}_{\mathrm{x}}, \mathrm{NH}_{3}$ and $\mathrm{PM}_{2.5}$ criteria pollutant emissions were reviewed in the literature. Due to the lack of data for buses, the effect was taken from experimental studies on light-duty vehicles by Suarez-Bertoa et al. [24] which indicate absolute emission factors for E5, E10, E15, E75, and E85. Hubbard, Anderson and Wallington [25] indicated relative differences between E0 and E10, E20, E30, E40, E55, and E80. Additionally Table 4 [26] includes several studies for finding E10 and E20 impacts on $\mathrm{NO}_{\mathrm{x}}$ and $\mathrm{PM}_{2.5}$ and shows an average impact of $-11.8 \%$ and $-17.1 \%$ for $\mathrm{NO}_{\mathrm{x}}$; and $-6 \%$ and $-36 \%$ for PM, respectively. From Table 4, we assume E80 impacts to be the same as for E100, or $-49 \%$ for $\mathrm{NO}_{x}$ and $153 \%$ for $\mathrm{NH}_{3}$. In our study we assume the correction factors, stated in Table 5 . The tendency for $\mathrm{NH}_{3}$ to increase with ethanol blends and $\mathrm{NO}_{x}$ and PM2.5 decrease is noteworthy.

\begin{tabular}{|c|c|c|c|c|c|c|}
\hline & \multicolumn{3}{|c|}{ [24] } & \multicolumn{3}{|c|}{ [25] } \\
\hline & $\begin{array}{c}\mathrm{NO}_{\mathrm{x}} \\
(\mathrm{mg} / \mathrm{km}) \\
\text { WLTP Cycle }\end{array}$ & $\begin{array}{c}\mathrm{NH}_{3} \\
\text { (mg/km) } \\
\text { WLTP Cycle }\end{array}$ & $\begin{array}{c}\mathrm{PM}_{2.5} \\
\text { (mg/km) } \\
\text { WLTP Cycle }\end{array}$ & $\begin{array}{c}\mathrm{NO}_{\mathrm{x}} \\
\text { (g/mile) FTP } \\
\text { Cycle }\end{array}$ & $\begin{array}{c}\mathrm{NH}_{3} \\
\text { (g/mile) FTP } \\
\text { Cycle }\end{array}$ & $\begin{array}{c}\mathbf{P M}_{2.5} \\
\text { (g/mile) FTP } \\
\text { Cycle }\end{array}$ \\
\hline E0 & NA & NA & NA & 0.0544 & 0.0353 & NA \\
\hline E5 & 62 & 6 & NA & NA & NA & NA \\
\hline E10 & 42 & 16 & NA & 0.0472 & 0.0408 & NA \\
\hline E15 & 51 & 14 & NA & NA & NA & NA \\
\hline E20 & NA & NA & NA & 0.0316 & 0.0638 & NA \\
\hline E30 & NA & NA & NA & 0.0245 & 0.0642 & NA \\
\hline E40 & NA & NA & NA & 0.0209 & 0.0705 & NA \\
\hline E55 & NA & NA & NA & 0.0293 & 0.0968 & NA \\
\hline E80 & NA & NA & NA & 0.0261 & 0.0896 & NA \\
\hline E85 & 19 & 26 & NA & NA & NA & NA \\
\hline
\end{tabular}

Table 4. Emission factors found in the literature for flex-fuel vehicles [24,25]. 
Table 5. $\mathrm{NO}_{\mathrm{x}}, \mathrm{NH}_{3}$ and $\mathrm{PM}_{2.5}$ assumed correction factors.

\begin{tabular}{cccc}
\hline & $\mathbf{N O}_{\mathbf{x}}$ & $\mathbf{N H}_{\mathbf{3}}$ & $\mathbf{P M}_{\mathbf{2 . 5}}$ \\
\hline E10 & $-12 \%$ & $+10 \%$ & $-6 \%$ \\
E20 & -17 & $+52 \%$ & $-36 \%$ \\
E80 & -49 & $+153 \%$ & $-36 \%$ \\
E100 & -49 & $+153 \%$ & $-36 \%$ \\
\hline
\end{tabular}

Criteria pollutants were obtained using Table 4 correction factors applied to Tier 2 emission factors for SI technology buses.

The new plug-in hybrid bus technology was based on the plug-in 7900 Electric Hybrid bus from Volvo (Table 6 and Figure 4). The internal combustion engine was replaced by a SI engine with the same rated power. Efficiency reasoning is used. In the literature [27-30]. The TTW efficiency varies but typically we may find $70-85 \%$ for a pure electric vehicle, $\mathrm{BEV}$, depending on the driving cycle.

Table 6. Technical specifications of plug-in 7900 Electric Hybrid bus from Volvo (PHEV).

\begin{tabular}{ll}
\hline Electric Motor & Max $160 \mathrm{~kW} / \mathrm{Max} 1200 \mathrm{Nm}$ \\
\hline Energy Storage System & Lithium ion battery $76 \mathrm{kWh}$ \\
\hline Transmission & Volvo 2-speed automatic transmission \\
\hline Charging System & $\begin{array}{l}\text { Opportunity charging-conductive charging } \\
\text { system-roof mounted. Fully automatic, fast } \\
\text { charging. Fast charging time: up to six minutes. }\end{array}$ \\
\hline Passenger Capacity & 83 \\
\hline Curb weight & 12 ton \\
\hline & Max. output 240 hp (177 kW) \\
& Max. power at $2200 \mathrm{rpm}$ \\
& Max. torque between $1200-1600 \mathrm{rpm} 918 \mathrm{Nm}$ \\
& No. of cylinders 4 \\
Engine Volvo D5K240 EU6 & Bore 110 mm \\
& Stroke $135 \mathrm{~mm}$ \\
& Displacement of $5.1 \mathrm{dm}$ \\
& Compression ratio of $17.5: 1$ \\
& Oil-change volume, including oil filters approx. 18.7 L \\
\hline
\end{tabular}

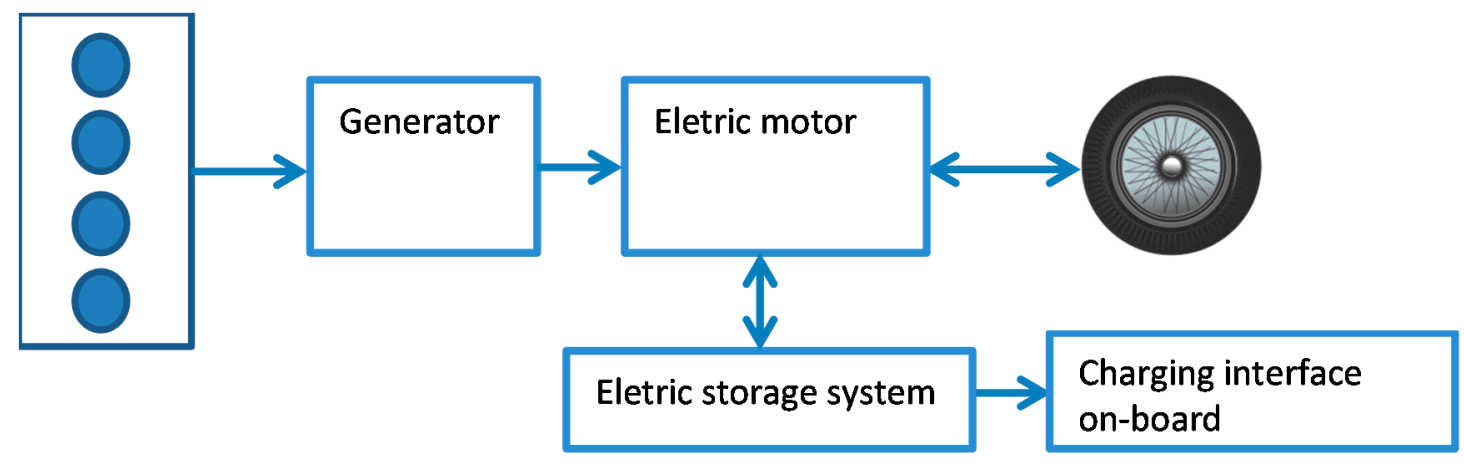

Figure 4. PHEV flex fuel powertrain.

According to the all-electric efficiency range assumed, $80 \%$ of the mileage is electric and $20 \%$ flex-fuel, were assumed to have an efficiency of $70-85 \%$ for all-electric and $21.7-30.7 \%$ for flex-fuel. That is, we assume a charge depleting energy management strategy and the $80 \%$ of $\mathrm{km}$ are like a pure electric vehicle, depleting the battery while the internal combustion engine is switched-off. The remaining $\mathrm{km}$ are like a hybrid internal combustion engine vehicle. The range is necessary because 
in our approach we want to cover most possible real driving situations and not just a specific driving cycle. The overall inputs to Equations (1) and (2) are given in Table 7.

The uncertainty sources were identified: fuel consumption/drivetrain efficiencies; and criteria emission factors. A maximum and minimum range in inputs were reflected in the model outcomes. $\mathrm{CO}_{2}$ emissions as a function of the fuel consumption had the same uncertainty levels. Regarding $\mathrm{NH}_{3}$, the minimum $\mathrm{PM}_{2.5}$ equivalency factor was 3.16 and the maximum 4.70. This gave us a $\mathrm{PM}_{2.5}$ equivalent range. For $\mathrm{NO}_{x}$ and $\mathrm{PM}_{2.5}$, the literature report usual uncertainties of $16 \%$ on average [31], without fuel correction and using the Tier 3 approach from EEA. A Tier 2 approach such as ours should have higher levels of uncertainty. Nevertheless, we stick to $16 \%$, to at least have a range of emissions. Uncertainty in the model input parameters is considered and is reflected in the results, by a uniform distribution (a minimum and maximum range).

Table 7. Inputs for fuel consumption and emissions calculations.

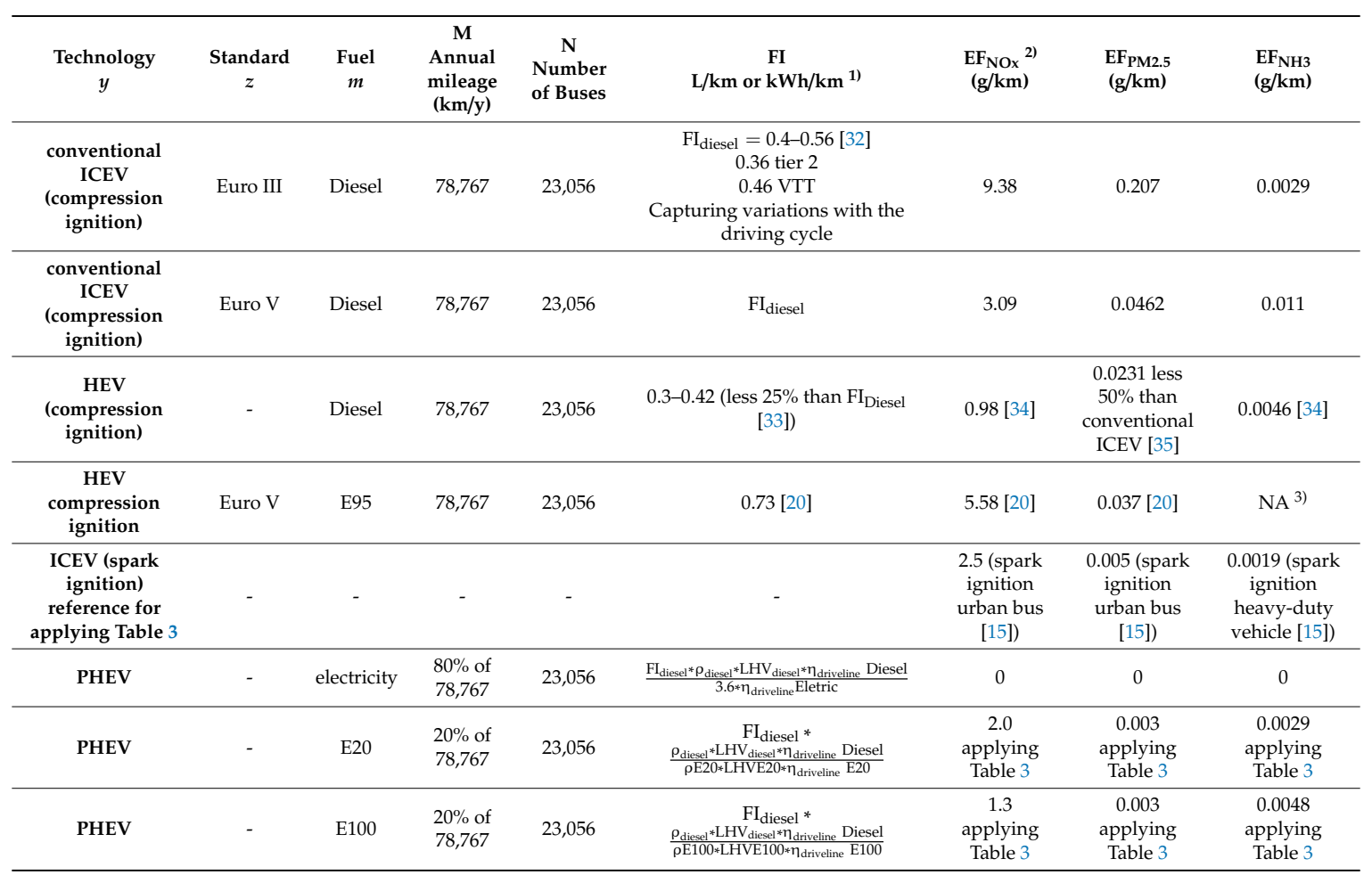

1) When electricity; 2) $\mathrm{NO}_{2}$ equivalent; 3) $10 \mathrm{ppm}$ limit in Euro VI, equivalent to a minimum of $0.05 \mathrm{~g} / \mathrm{km}$ assuming the stoichiometric combustion ratio of 9 , a lambda of 18 , typical for idle, and exhaust molar mass of $29 \mathrm{~kg} / \mathrm{kmol}$.

\section{Results}

Runs of the ADVISOR microsimulation model [10-12], for one specific driving cycle with 12 stops, were crosschecked with reviewed literature data on powertrain component efficiency (Figure 5). The fuel converter (ICE) efficiency of a conventional diesel bus, an HEV and a PHEV (with charge depleting management strategy) buses are depicted, as well as their powertrain component efficiencies. 

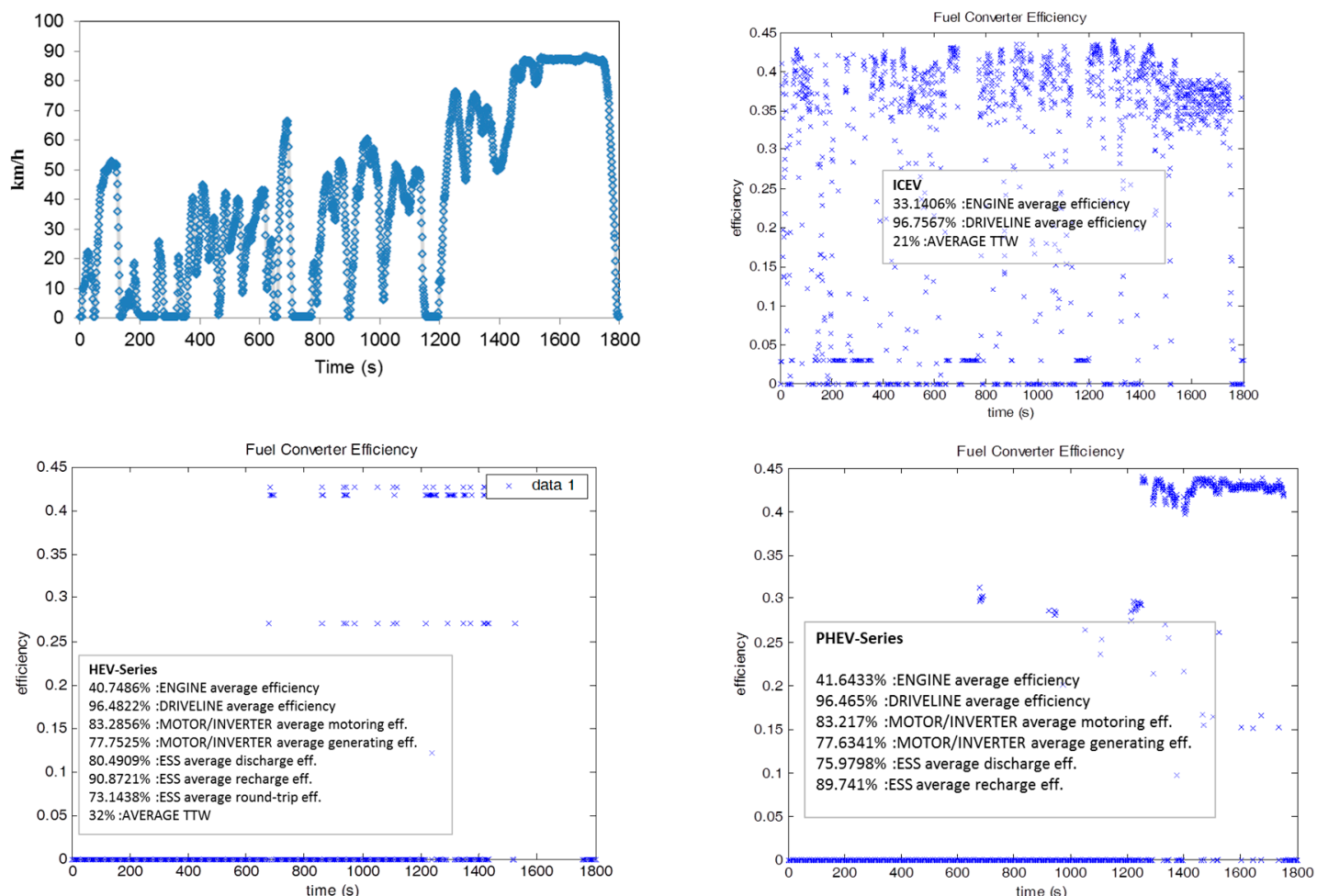

Figure 5. ADVISOR model efficiencies for a specific driving cycle and PHEV energy management (average speed $40 \mathrm{~km} / \mathrm{h}$, distance $20 \mathrm{~km}, 12$ stop-\&-go situations). "Cross check" of efficiency assumptions.

As we can see in Figure 5, the efficiencies fall in the ranges reviewed so we stick with our simplified approach for the analysis of WTW. Considering the macro approach of fuel intensity and powertrain efficiency ratio seems to be suitable and intends to cover as much of driving situations as possible. Considering this macro approach, the final energy consumption is depicted in Table 8 for the reference and alternative scenarios.

Table 8. Final energy consumption by source and per year, with uncertainty.

\begin{tabular}{ccccc}
\hline & Electricity GWh & Diesel ML & Gasoline ML & Ethanol ML \\
\hline ICEVdiesel-Reference & - & $835.38(654-1017)$ & - & - \\
Euro III bus fleet & - & $626.54(490-763)$ & - & - \\
HEVdiesel & - & - & - & 1325.72 \\
HEVED95 & $2215.99(1642-4385)$ & - & $164.73(105-326)$ & $41.18(26-82)$ \\
PHEVflexE20 & $2215.99(1624-4385)$ & - & - & $281.34(179-557)$ \\
PHEVflexE100 &
\end{tabular}

So, if Ecuador decides to hybridize the bus fleet on ED95, it will have to produce roughly 1326 million litres of ethanol a year to satisfy the final energy demand. This means that the potential ethanol production either from sugarcane ( 80 million $\mathrm{L}$ a year) or banana industry waste (40 million $\mathrm{L}$ a year) will not be enough. If the option is to move forward with a PHEV flex fleet, the ethanol demand is much lower, 41-281 million L, which could not yet be met by banana industry waste. Ethanol production through the sugarcane industry could meet around $42 \%$ of the maximum ethanol production required for this case. The sugarcane industry must, in any case, provide most of the required fuel.

In terms of air quality, of course, the PHEV scenarios would be better because it was assumed that $80 \%$ of the mileage is all-electric, with zero local emissions. Nevertheless, the introduction of ethanol could increase $\mathrm{NH}_{3}$ particle precursors and if we look to the equivalent $\mathrm{PM}_{2.5}$ in Table 9, the hybrid 
ED95 fleet could be the worst-case scenario. The higher $\mathrm{NH}_{3}$ emissions in $\mathrm{HEV}_{\text {diesel }}$ are due to the $\mathrm{SCR}$ NOx exhaust aftertreatment system and the reduced $\mathrm{PM}_{2.5}$ to the particle filters.

Table 9. Criteria pollutants for the Ecuadorian bus fleet in ton/year, with uncertainty.

\begin{tabular}{ccccc}
\hline & $\mathbf{N O}_{\mathbf{2}}$ & $\mathbf{P M}_{\mathbf{2 . 5}}$ & $\mathbf{N H}_{\mathbf{3}}$ & $\mathbf{P M}_{\mathbf{2 . 5}}$ Equivalent \\
\hline ICEV-Reference & $17,034.6(14,309-19,760)$ & $375.9(318-434)$ & 5.3 & $396.5(338-455)$ \\
Euro III bus fleet & $1779.7(1495-2065)$ & $42.0(35-49)$ & 83.5 & $368.3(364-376)$ \\
HEV diesel & $10,133.6(8512-11,755)$ & $67.2(78-95)$ & 95.3 & $439.7(429-450)$ \\
HEV ED95 & $753.7(633-874)$ & $1.2(1-1.3)$ & 1.0 & $5.3(5.1-5.4)$ \\
PHEV E20 & $463.1(389-537)$ & $1.2(1-1.3)$ & 1.7 & $8.0(7.8-8.2)$ \\
PHEV E100 & &
\end{tabular}

The TTW $\mathrm{CO}_{2}$ emissions are a part of a future study on a WTW approach and are depicted in Figure 6. It is worth noting that there is considerable mitigation of TTW $\mathrm{CO}_{2}$ emissions, around $78-80 \%$ when conventional fleet buses are replaced with plug-in hybrid buses It is interesting to note that the $\mathrm{HEV}_{\mathrm{ED} 95}$ has higher TTW $\mathrm{CO}_{2}$ emissions due to the higher fuel consumption phenomena that overlap the lower $\mathrm{CO}_{2}$ formation per litre of ethanol burned in comparison to diesel fuel $\left(1.5 \mathrm{kgCO}_{2} / \mathrm{L}\right.$ ethanol versus $2.7 \mathrm{kgCO}_{2} / \mathrm{L}$ diesel). The diesel-ethanol HEV-ED95 technology energy consumption and $\mathrm{CO}_{2}$ emissions were derived from the LIPASTO database on-road measurements and have no reported uncertainty.

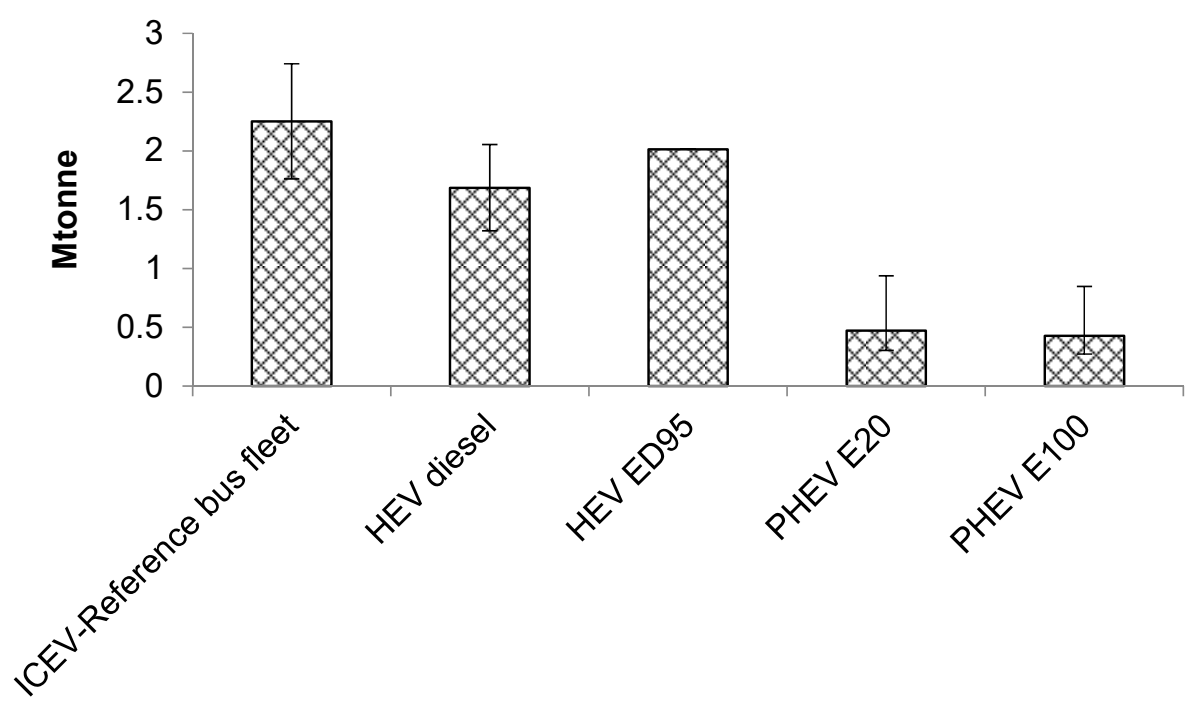

Figure 6. TTW $\mathrm{CO}_{2}$ emissions for the Ecuadorian bus fleet in millions ton/year, with uncertainty (range based with uniform distribution).

Additionally, observing the WTW values in Figure 7, clearly electrification of the bus fleet has more positive impacts on the air quality and global warming impact than moving to a bioeconomy bus fleet system. However, the flexibility of supplying a PHEV with three possible energy sources instead of just electricity is noteworthy. 


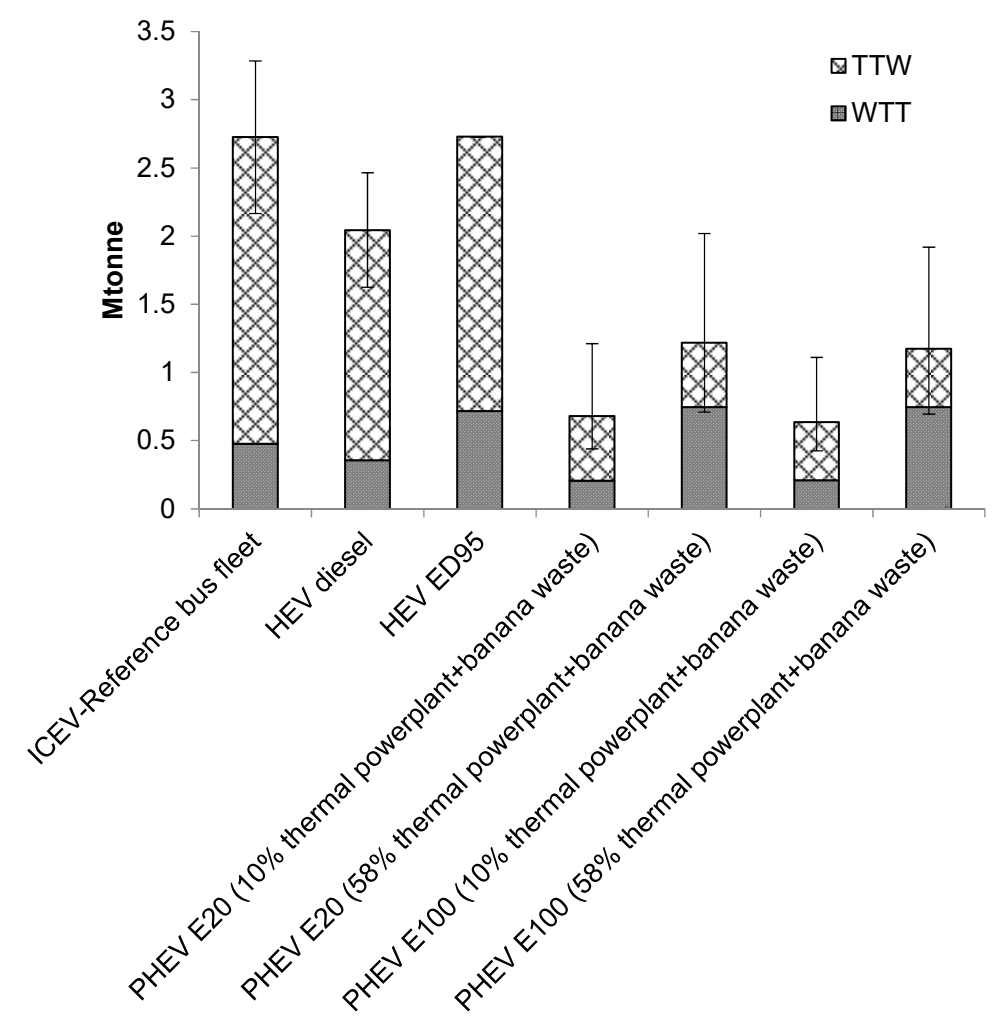

Figure 7. WTW $\mathrm{CO}_{2}$ emissions for Ecuadorian bus fleet in millions ton/year, with uncertainty (range based with uniform distribution).

\section{Discussion}

These are preliminary results due to the limitations/constraints of the work. One main limitation is the lack of hybrid CI diesel and hybrid ED95 bus data in the EEA emission inventory guidebook [15]; therefore the bus technologies are not compared using the same database. The ethanol effect on $\mathrm{PM}_{2.5}$ in flex-fuel engines is also barely reported in the literature and should be explored experimentally. $\mathrm{NH}_{3}$ emissions need more experimental data because are they are particle precursors and are already limited in new European and American regulations to $10 \mathrm{ppm}$ in exhaust gases. These values are barely seen in the reviewed literature. However, the uncertainty given in the results could partially reflect these weaknesses and be taken as a preliminary result indicating whether Ecuador should pursue a bioeconomy.

In this context, the food vs. biofuels discussion will be intensified. However, Ecuador may choose to continue producing sugar and its derivatives and producing ethanol through surplus bagasse, in a biorefinery context. For example, Cavalett et al. [36] and and Corrêa do Lago et al. [37] definitely demonstrate the positive sugarcane conditions for the development of second generation ethanol (non-food competitive) at least at the Brazilian context. Again the flexibility of a vehicle running on three possible fuels is highlighted. Moving heavily to renewables in the future and having only $10 \%$ of electricity provided by thermal powerplants (coal or natural gas) should be addressed.

\section{Conclusions}

As an explorative study this paper shows some novel concepts in terms of a new possible PHEV bus powertrain and a conversion factor for $\mathrm{NH}_{3}$ emissions to $\mathrm{PM}_{2.5}$ equivalent emissions. The simplified model of using a range of fuel intensities and typical final to useful energy conversion efficiencies was crosschecked with a microsimulation model that allows the efficiency data variation at various speeds and acceleration/deceleration rates. 
The metrics calculated in this research were, final energy consumption (by source), air quality related pollutants, $\mathrm{NO}_{\mathrm{x}}$ (as $\mathrm{NO}_{2}$ equivalent), $\mathrm{NH}_{3}$, and $\mathrm{PM}_{2.5}$ equivalent, and 100 years global warming potential (as $\left.\mathrm{CO}_{2} \mathrm{eq}\right)$.

If the diesel energy source is to be kept, hybrid technology is a good option for a replacement, reducing fuel consumption and TTW $\mathrm{CO}_{2}$ emissions by $25 \%$, but, despite the particle filters, only reducing $7 \%$ the $\mathrm{PM}_{2.5}$ equivalent emissions.

If an ethanol energy source is seen as the future, and energy supply flexibility to the bus is a priority, the best option to reduce emissions will be the plug-in hybrid flex-fuel vehicles. However, Ecuador still needs more investment in ethanol production. The current capacity (considering ethanol production through sugarcane and banana waste) will not be enough to satisfy the demand and it will be imperative to boost ethanol production through larger extensions of cultivated area and sugarcane biorefineries. These new technologies will provide a $55-77 \% \mathrm{CO}_{2}$ eq reduction, even if coal is used in the thermal powerplant, on a heavy renewables penetration scenario.

A future study on sugarcane biorefineries sustainability in Ecuador will bring the carbon footprint (well-to-wheels) benefits of such PHEV flex-fuel bus system to the discussion.

Author Contributions: D.A. as Ph.D. student did the calculations, C.S. as supervisor guided the calculations and contributed to the writing.

Funding: This research received no external funding.

Acknowledgments: Publication supported by FCT- project UID/GEO/50019/2019-Instituto Dom Luiz. This paper is also supported by Escuela Superior Politécnica del Litoral (ESPOL). We wish to acknowledge the Municipal Transit Agency of Guayaquil (ATM) for providing us the information to develop this study. Thanks to the English proofreading service that helped with the English quality of the manuscript.

Conflicts of Interest: The authors declare no conflict of interest.

\section{References}

1. Oliveira, M.L.M.; Silva, C.M.; Moreno-Tost, R.; Farias, T.L.; Jiménez-López, A.; Rodríguez-Castellón, E. Modelling of NOx emission factors from heavy and light-duty vehicles equipped with advanced aftertreatment systems. Energy Convers. Manag. 2011, 52, 2945-2951. [CrossRef]

2. Stelwagen, U.; Ligterink, N. NH3 Emission Factors for Road Transport; TNO: Ultrecht, The Netherlands, 2015.

3. Baek, B.H.; Koziel, J.A.; Aneja, V.P. A preliminary review of gas-to-particle conversion monitoring and modelling efforts in the USA. Int. J. Glob. Environ. Issues 2015. [CrossRef]

4. INEC. Anuario de Transporte 2015. Inf. Anu. 2015, 46.

5. Graefe, S.; Dufour, D.; Giraldo, A.; Muñoz, L.A.; Mora, P.; Solís, H.; Gonzalez, A. Energy and carbon footprints of ethanol production using banana and cooking banana discard: A case study from Costa Rica and Ecuador. Biomass Bioenergy 2011, 35, 2640-2649. [CrossRef]

6. Guerrero, A.B.; Muñoz, E. Life cycle assessment of second generation ethanol derived from banana agricultural waste: Environmental impacts and energy balance. J. Clean. Prod. 2018. [CrossRef]

7. Ponce-Jara, M.A.; Castro, M.; Pelaez-Samaniego, M.R.; Espinoza-Abad, J.L.; Ruiz, E. Electricity sector in Ecuador: An overview of the 2007-2017 decade. Energy Policy 2018. [CrossRef]

8. MEER. Plan Nacional De Eficiencia Energética-PLANEE (Versión 2016-2035); Ministerio de Eletricidade y Energia Renovable: Quito, Ecuador, 2017.

9. Samaniego, M.P.; Abad, J.E. Eficiencia energética y ahorro de energía en el Ecuador; Universidad Cuenca: Cuenca, Ecuador, 2015.

10. Ribau, J.P.; Silva, C.M.; Sousa, J.M.C. Plug-in hybrid vehicle powertrain design optimization: Energy consumption and cost. Lect. Notes Electr. Eng. 2013, 191, 595-613.

11. Silva, C.M.; Farias, T.L.; Frey, H.C.; Rouphail, N.M. Evaluation of numerical models for simulation of real-world hot-stabilized fuel consumption and emissions of gasoline light-duty vehicles. Transp. Res. Part $D$ Transp. Environ. 2006, 11, 377-385. [CrossRef]

12. Markel, T.; Brooker, A.; Hendricks, T.; Johnson, V.; Kelly, K.; Krämer, B.; O’Keefe, M.; Sprik, S.; Wipke, K. ADVISOR: A systems analysis tool for advanced vehicle modeling. J. Power Sources 2002, 110, 255-266. [CrossRef] 
13. Cooney, G.; Jamieson, M.; Marriott, J.; Bergerson, J.; Brandt, A.; Skone, T.J. Updating the U.S. life cycle GHG petroleum baseline to 2014 with projections to 2040 using open-source engineering-based models. Environ. Sci. Technol. 2017. [CrossRef]

14. DieselNet. 2014. Available online: www.dieselnet.com (accessed on 1 May 2019).

15. Kouridis, C.; Samaras, C.; Hassel, D.; Mellios, G.; Mccrae, I.; Hickman, J.; Zierock, H.; Keller, M.; Rexeis, M.; Andre, M.; et al. EMEP/EEA Air Pollutant Emission Inventory Guidebook; European Environment Agency: Luxemburg, 2018.

16. Kogo, T.; Hamamura, Y.; Nakatani, K.; Toda, T.; Kawaguchi, A.; Shoji, A. High Efficiency Diesel Engine with Low Heat Loss Combustion Concept-Toyota's Inline 4-Cylinder. SAE Int. 2016. [CrossRef]

17. Thiruvengadam, A.; Pradhan, S.; Thiruvengadam, P.; Besch, M.; Carder, D.; Delgado, O. Heavy-Duty Vehicle Diesel Engine Efficiency Evaluation and Energy Audit. In Center for Alternative Fuels, Engines E Emissions: West Virginia University Final Report; West Virginia University: Morgantown, WV, USA, 2014.

18. Zheng, J.; Song, C.; Peng, Q.; Wang, Z. Experimental Study on Transmission Efficiency of Hybrid Electric Bus Transmission with Synthetic Box Assembly. In Proceedings of the 2012 Asia-Pacific Power and Energy Engineering Conference, Shanghai, China, 27-29 March 2012. [CrossRef]

19. Heywood, J.B. Internal Combustion Engine Fundamentals; McGraw-Hill: Singapore, 1988.

20. Nylund, N.O.; Laurikko, J.; Laine, P.; Suominen, J.; Anttonen, M.P.A. Benchmarking heavy-duty ethanol vehicles against diesel and CNG vehicles. Biomass Convers. Biorefin. 2013. [CrossRef]

21. Leone, T.G.; Anderson, J.E.; Davis, R.S.; Iqbal, A.; Reese, R.A.; Shelby, M.H.; Studzinski, W.M. The Effect of Compression Ratio, Fuel Octane Rating, and Ethanol Content on Spark-Ignition Engine Efficiency. Environ. Sci. Technol. 2015. [CrossRef]

22. Edwards, K.D.; Wagner, R.M.; Briggs, T.E.; Theiss, T.J. Defining Engine Efficiency Limits. In Proceedings of the 17th DEER Conference, Detroit, MI, USA, 3-6 October 2011.

23. Wang, R.; Wu, Y.; Ke, W.; Zhang, S.; Zhou, B.; Hao, J. Can propulsion and fuel diversity for the bus fleet achieve the win-win strategy of energy conservation and environmental protection? Appl. Energy 2015, 147, 92-103. [CrossRef]

24. Suarez-Bertoa, R.; Zardini, A.A.; Keuken, H.; Astorga, C. Impact of ethanol containing gasoline blends on emissions from a flex-fuel vehicle tested over the Worldwide Harmonized Light duty Test Cycle (WLTC). Fuel 2015, 143, 173-182. [CrossRef]

25. Hubbard, C.P.; Anderson, J.E.; Wallington, T.J. Ethanol and air quality: Influence of fuel ethanol content on emissions and fuel economy of flexible fuel vehicles. Environ. Sci. Technol. 2014. [CrossRef] [PubMed]

26. Mueller, S.; Unnasch, S.; Keesom, B.; Mohan, S.; Goyal, L. The Impact of Higher Ethanol Blend Levels on Vehicle Emissions in Five Global Cities; University of Illinois: Chicago, IL, USA, 2018.

27. Silva, C.; Ross, M.; Farias, T. Analysis and simulation of "low-cost" strategies to reduce fuel consumption and emissions in conventional gasoline light-duty vehicles. Energy Convers. Manag. 2009, 50, 215-222. [CrossRef]

28. Eaves, S.; Eaves, J. A cost comparison of fuel-cell and battery electric vehicles. J. Power Sources 2004. [CrossRef]

29. Righolt, H.C.; Rieck, F.G. Energy chain and efficiency in urban traffic for ICE and EV. In Proceedings of the 2013 World Electric Vehicle Symposium and Exhibition, Barcelona, Spain, 17-20 November 2013. [CrossRef]

30. Kappel, J.; Mathiesen, B.V. Screening of Tank-to-Wheel Efficiencies for CNG, DME and Methanolethanol Fuel Blends in Road Transport; Aalborg University: Aalborg, Denmark, 2013.

31. Kouridis, C.; Gkatzoflias, D.; Kioutsioukis, I.; Ntziachristos, L.; Pastorello, C.; Dilara, P. Uncertainty Estimates and Guidance for Road Transport Emission Calculations; European Commission Joint Research Centre, Institute for Environment and Sustainability: Ispra, Italy, 2010.

32. Bradley, M.J. Bus Technology \& Alternative Fuels Demonstration Project; FINAL Phase 1-TEST PROGRAM REPORT; M.J. Bradley \& Associates: Washington, DC, USA, 2006.

33. Zhang, S.; Wu, Y.; Liu, H.; Huang, R.; Yang, L.; Li, Z.; Fu, L.; Hao, J. Real-world fuel consumption and CO2 emissions of urban public buses in Beijing. Appl. Energy 2014, 113, 1645-1655. [CrossRef]

34. Keramydas, C.; Papadopoulos, G.; Ntziachristos, L.; Lo, T.S.; Ng, K.L.; Wong, H.L.; Wong, C. Real-World Measurement of Hybrid Buses' Fuel Consumption and Pollutant Emissions in a Metropolitan Urban Road Network. Energies 2018, 11, 2569. [CrossRef]

35. Hallmark, S.L.; Wang, B.; Sperry, R. Comparison of on-road emissions for hybrid and regular transit buses. J. Air Waste Manag. Assoc. 2013, 63, 1212-1220. [CrossRef] [PubMed] 
36. Cavalett, O.; Chagas, M.F.; Seabra, J.E.A.; Bonomi, A. Comparative LCA of ethanol versus gasoline in Brazil using different LCIA methods. Int. J. Life Cycle Assess. 2013. [CrossRef]

37. Corrêa do Lago, A.; Bonomi, A.; Cavalett, O.; Pereira da Cunha, M.; Pinheiro Lima, M.A. Sugarcane as a carbon source: The Brazilian case. Biomass Bioenergy 2012. [CrossRef] 